to say that the quality of the teaching in any institution must depend upon the qualifications of the teachers, and that none of the three Colleges I have named need shrink from a comparison in this respect with any Government school at present in existence.

In answer to these considerations it might perhaps be urged that it is the duty of Government to secure elficient public servants, and that they are not called upon to consider how far private institutions are benefited or injured by the means that appear necessary for this purpose. To this I reply that, even adopting for the sake of argument this point of view, it is the imperative duty of Government not to spend public funds in doing what is already well done by private effort; and that, if anything was required which is not already supplied, public money would be far more productively expended in helping existing institutions to supply the defect, than in founding a new institution which will have to be supported entirely at the national expense. The obviously proper plan is for Government to test the qualifications of candidates for the public service with any degree of strictriess they may think proper, but not to burden the country with the expense of educating them.

Perhaps, however, the assumption with which I started may be entirely wrong, and the proposed Engineering College may be intended to supply only a purely professional training. If this be so, there is even less to be said for it than before. In this case it will be merely a "Technical School," attempting to impart the knowledge and experience which can only be really acquired by actual practice under a working engineer.

In any case it seems strange that Government should announce its intention of establishing an Engineering College at the very time when a Royal Commission is making "inquiry with regard to Scientific Instruction,

derived from grants voted by Parliament."

University College, London, Aug. I5

G. C. Foster

\section{OUR SALAD HERBS}

THERE is perhaps no country in the world so rich as England in native materials for salad-making, and none in which ignorance and prejudice have more restricted their employment. At every season of the year the peasant may cull from the field and hedge-row wholesome herbs which would impart a pleasant variety to his monotonous meal, and save his store of potatoes from premature exhaustion; and there can be no question that in hot seasons a judicious admixture of fresh green food is as salutary as it is agreeable. Much has been said lately about the advantage which the labouring man would derive from an accurate acquaintance with the various sorts of fungus, and he has been gravely told that the Fistulina hepatica is an admirable substitute for beef-steak, and the Agaricus gambosus for the equally unknown veal cutlet. But deep-rooted suspicion is not easily eradicated, and there will alwavs be a certain amount of hazard in dealing with a class of products in which the distinctions between noxious and innocuous are not very clcarly marked. There is not this difficulty with regard to salad herbs, and we conceive that the diffusion of a little knowledge as to their properties and value would be an unmixed benefit to our rural population.

The first place must be assigned, on the score of antiquity, to the sorrel plant (Rumex acetosa), which in some districts still preserves the name of "green sauce," assigned to it in early times when it formed almost the only dinner vegetable. Its acid is pleasant and wholesome, and more delicate in flavour than that of the wood-sorrel (Oxalis acetosa), which, however, is used for table purposes in France and Germany. Chervil (Anthriscus cerefolium) is often found in a wild state and is an admirable addition to the salad bowl; and it is unnecessary to enlarge upon the virtues of celery (Apizm graveolens) when improved by cultivation. John Ray, writing in 1663 , says that "The Italians use several herbs for sallets which are not yet, or have not been used lately, but in England,viz., selleri, which is nothing else but the sweet smallage; the young shoots whereof, with a little of the head of the root cut off, they eat raw with oil and pepper;" and to this we may add that the alisander (Smyrnizm olusatrum) is no bad substitute for its better known congener. The dandelion, which in France is blanched for the purpose, affords that amari aliquid which the professed salad maker finds in the leaves of the endive, and the same essential ingredient may be supplied by the avens (Geum urbanum), the bladder campion (Silene inflata), and the tender shoots of the wild hop. Most people are familiar with the properties of the water cress (Nasturtium officinale), and the garlic hedge mustard (Erysimnm alliaria); but it may not be generally known that the common shepherd's purse (Capsella bursa-pastoris) and Lady's smock (Cardamine pratensis) are pleasant additions, whose merits have long been recognised by our foreign neighbours. In fact there is scarcely a herb that grows which has not some cultinary virtue in a French peasant's eyes. Out of the blanched shoots of the wild chicory (Cichorium intybus), he forms the well-known Barbe des Capucins, and dignifies with the title of Salade de Chanoine our own neglected corn salad (Fedia olitoria). It would be very easy to extend the dimensions of our list of native salad herbs, for there are, perhaps, some palates to which the strong flavours of the chive (Allium schanoprasum) and stone-crop (Sedum reflexum) may commend themselves, but enough has been said to show that Nature has not dealt niggardly with us, and that only knowledge is needful to make the riches she offers available. If the British peasant can be taught to discover hidden virtues in these plants with whose outward forms he has had life-long familiarity, we do not despair of his acquiring the one secret of salad-making, viz., the judicious employment of oil so as to correct the acrid juices of the plants and yet preserve their several flavours unimpaired.

C. J. ROBINSON

\section{TESTIMONIAL TO PROF. MORRIS, F.G.S.}

THE presentation of a testimonial to Prof. Morris on July I4, was the occasion of the meeting of nearly one hundred gentlemen, occupying prominent positions in connection with geology and the allied sciences.

Sir Roderick I. Murchison, Bart., K.C.B., occupied the chair, and, in opening the business of the day, expressed the sincere gratification he experienced in having been requested by the subscribers to this Testimonial to act as Chairman on an occasion when it was sought to do honour to Prof. Morris, whom he highly esteemed as a geologist, and whom he loved as a friend. He then gave a sketch of the career of Prof. Morris as a geologist, showing that in his earlier researches he was among the first to make most valuable communications upon the structure and fossil contents of the Tertiary formation of the South and East of England; and how he next threw much new light upon various members of the Oolitic formation and the Lias, describing the fossil contents with great acumen and ability. These were followed by his opus magnum, the "Catalogue of all British Fossils," which had gone through two editions, and was a work which would for ever hold a high place in science, as a truthful record of the succession of all classes of known animals from the earliest traces of life to those of the youngest Tertiary formations connecting ancient with existing nature.

The address was then presented, as follows:-

To John Morris, Esq., F.G.S., Professor of Geology in University College, London.

We, the undersigned, Friends and Cultivators of Geology, taking into consideration the degree in which this science has been advanced by your long and successful labours, are desirous of uffering to you a Testimonial of the high estimation in which they are held. Always working in the field, and classifying public and private collections, you have for many years been among the foremost and most diligent of the Students o 